GENETICS

\title{
Attitudes of healthcare professionals and parents regarding genetic testing for violent traits in childhood
}

\author{
E Campbell, L F Ross
}

J Med Ethics 2004;30:580-586. doi: 10.1136/jme.2003.005389

See end of article for authors' affiliations

ar.

Correspondence to: Dr L Ross, University of Chicago, Department of Pediatrics, $5841 \mathrm{~S}$. Maryland Ave, MC 6082, Chicago IL 60637, USA;

Iross@uchicago.edu

Received 19 June 2003

In revised form

2 October 2003

Accepted for publication

21 October 2003
Objectives: Although no genetic tests for violent behaviour are currently available, research is ongoing to isolate genes related to a propensity for violence. We explored the attitudes of parents and healthcare professionals toward behavioural genetic testing for violence.

Design: The attitudes of healthcare professionals and the lay public about genetic testing of children were elicited for a range of conditions through interviews with healthcare professionals and focus groups with parents. All participants were informed that behavioural genetic testing was the only hypothetical genetic test in our script and it was presented as the last condition.

Participants: The healthcare professionals included both genetic professionals and paediatricians. Focus group participants were recruited through various community institutions in the southside of Chicago and nearby suburbs.

Results: The healthcare professionals tended to medicalise behavioural genetics, and were opposed to testing unless treatment was available. They were also uniformly concerned about the potential harms of this information, including unintentional adverse effects from environmental changes. In contrast, parents wanted genetic testing for behavioural traits to be available even in the absence of proved medical treatments. Not all parents wanted to test their own children, and some parents were concerned about selffulfilling prophecies. Some parents, however, felt the information was important for their understanding, and could be used to support environmental changes.

Conclusions: While healthcare professionals medicalised behavioural genetics, parents focused on environmental causes and influences. Consequently, healthcare professionals do not want to offer testing if there is no clear treatment, while parents may want this information to shape environmental influences.
W hile genetic research has yielded accurate genetic tests for some single-gene conditions (for example Huntington's disease, Duchenne's muscular dystrophy), research continues into a wide range of multifactorial conditions (for example heart disease, diabetes, and behavioural traits) that will be explained only partially by the isolation of a gene or group of genes. These genetic tests will not be diagnostic but will confirm or refute only an increased propensity or susceptibility for a particular condition. Included in this research is research into behavioural genetics, particularly the genetics of violence or aggression.

A historical review shows that genetic research into violence has been rife with misunderstanding. In 1965, Jacobs et al reported findings from their research into residents of a Scottish mental hospital that an increased number of "mentally sub-normal male patients with dangerous, violent, or criminal propensities" possessed an extra $\mathrm{Y}$ chromosome. ${ }^{1}$ Follow up research found that the initial link of an extra Y chromosome with a propensity to violence was due to a sample bias. ${ }^{2}$ In 1974, Dr Stanley Walzer at Harvard had begun to screen newborn males for XYY as part of a prospective long term study to describe the physical and mental development of a large number of these boys in an unselected population. There was much public and academic controversy about whether the study could yield meaningful results because of the potential of the study design to create a self-fulfilling prophecy. Others argued that the risks outweighed the benefits, and the research should be stopped on ethical grounds. In June 1975, Walzer voluntarily stopped the research because of "unrelenting pressure from advocacy groups." ${ }^{3}$ Despite controversy and eventual discrediting of the XYY association with crime, lawyers attempted to use it to absolve their clients of responsibility or to mitigate punishment in cases in the USA, France, and Australia. ${ }^{4-6}$

Another example of behavioural genetic research involves the enzyme monoamine oxidase A (MAOA). In 1993, Harm G Brunner in the Netherlands announced he had found a family of Dutch criminals who suffered from a defect in the gene that determines MAOA production. ${ }^{7}$ In 1996, Brunner denied that the data support the hypothesis that MAOA constitutes an "aggression gene" ${ }^{\prime \prime}$ :

In fact, because genes are essentially simple and behaviour is by definition complex, a direct causal relationship between a single gene and a specific behaviour is highly unlikely. In the case of MAOA deficiency, some of the complexities are illustrated by the variability in the behavioural phenotype, as well as by the highly complex effects of MAOA deficiency on neurotransmitter function. Thus, the concept of a gene that directly encodes behaviour is unrealistic.

Despite this, in at least one case, lawyers have argued for genetic testing for MAOA for a client as their basis for an appeal to avoid the death penalty. ${ }^{910}$

While there have been several examinations of ethical and policy issues regarding behavioural genetics, ${ }^{411-13}$ the Nuffield Council on Bioethics in the UK was the first and has been the only genetics organisation thus far to examine comprehensively the issues of genetic testing and human behaviour. ${ }^{14}$ The monograph begins by noting that no tests currently exist for behavioural genetic conditions and that there is disagreement about whether accurate tests could be developed. Regardless, the Council noted that tests may be 
developed that suggest an increased chance of possessing a particular behavioural trait, but that expression would depend upon how various genes interact as well as environmental factors, and genetic-environmental interactions. ${ }^{14}$

Nonetheless, if behavioural genetic tests are developed, there are both potential risks and benefits. The risks include oversimplification of complex multifactorial conditions (genetic determinism), the potential for stigmatisation and discrimination, and the potential use of untested treatments and preventive measures in children with a predisposition but not necessarily affected. Potential benefits include improved diagnosis and/or treatment and psychosocial benefits in the preparation of families and affected individuals. ${ }^{15-18}$

Although we concur with the Nuffield Council that any explanation of violent behaviour will include both genetic and environmental factors, media reports on the "gay gene $^{\prime 19-21}$ or the "gene for intelligence" $e^{\prime 22-24}$ encourage an attitude of genetic determinism..$^{25}$ Of note, the concern with genetic determinism persists. ${ }^{26}{ }^{27}$ Furthermore, as suggested by Rose, this genetic determinism may be appealing to governments which can benefit from a genetic basis for a complex social condition such as violence or aggression: "If it is all in the genes, governments can avoid the hard problems of social engineering in favour of funding research on molecular technology." 28 And indeed there are policy initiatives to support genetic determinism. As Murray notes, much of the push for special privacy legislation for genetics is based on a notion of "genetic exceptionalism", that genetic information is somehow different from other medical information. ${ }^{29}$

Given the potential risks and benefits of behavioural genetic tests and the compelling power of genetic explanations to the lay public, we sought to understand the attitudes and beliefs of both healthcare professionals and parents regarding the desirability of developing genetic testing for violent behaviours. While the Nuffield Council had sought public consultation, many of their respondents were academics and professionals. ${ }^{30}$ Our public consultation via community focus groups involved parents without genetic or medical expertise, and thereby hears from voices often missed out in the academic debates.

\section{METHODS}

This paper relies on data collected from semistructured interviews with healthcare professionals and focus groups with parents. In both interviews and focus groups, the researchers presented a range of scenarios involving testing for different genetic conditions. Details of the methods are given elsewhere (reference 31 and unpublished data). Briefly, semistructured interviews with 25 healthcare professionals ( 15 women (60\%), 10 men (40\%); age range $28-55$ years) were conducted by a physician knowledgeable about paediatrics and genetics (LFR). There were 13 genetic professionals (GEN) from 10 institutions or practice sites and 12 paediatricians (PED) from nine institutions or practice sites. Five of the genetic professionals had masters degrees in genetic counselling, while eight were physicians (six of whom were paediatricians). Of the paediatricians, seven had fellowship training beyond paediatric residency. Sixteen $(64 \%)$ reported having children.

The interview examined issues of access and confidentiality with respect to genetic testing of children for conditions beginning with newborn screening for phenylketonuria (PKU), followed by newborn screening for Duchenne's muscular dystrophy (DMD), predictive screening for familial adenomatous polyposi (FAP), breast cancer mutation BRCA1 (BRCA), apolipoprotein E4 (ApoE), carrier status for an autosomal recessive condition, and concluding with genetic testing for a behaviour. For behavioural genetics, 21 respondents were asked to consider their attitudes if genetic tests became available that correlated with an increased predisposition to violence or aggression, while four were asked to consider the scenario of genetic tests that correlated with an increased predisposition to high intelligence. The latter are excluded from this analysis. Specifically with respect to a predisposition to violence, respondents were asked to describe: $(a)$ the pros and cons of testing for the child and family; (b) their policy recommendations for testing children and adolescents; and (c) whether they would seek testing of their children or permit their adolescents to procure testing.

The other component of this study is based on focus groups conducted in the Chicago area. We conducted 12 focus groups comprised of 4-12 respondents from diverse economic and ethnic communities. Overall there were 102 respondents (84 women, 18 men; average age 39.36 years, range 18-69). Seven focus groups were composed of black respondents only. Additionally, three focus groups had a mix of white and black respondents, and two focus groups had only white respondents. Eight focus groups were composed of both men and women while four had only women.

On average, respondents reported having 2.47 children (range 1-7). The range of children's ages reported was from 3 weeks to 50 years of age, with the youngest child averaging 8.52 years, and the oldest averaging 14.74. Most (84/102) respondents reported living with their children and almost a quarter (24/102) reported living with a child with a chronic illness. The information above was collected through a voluntary, anonymous, post-focus group survey. Upon the advice of the advisory board to this project, extensive demographic information including education and income was not collected.

The focus groups were asked to discuss five scenarios in the following order: newborn screening for PKU and DMD, genetic testing of young children for BRCA and carrier status, and genetic testing for a behavioural trait. In 11/12 focus groups, violence was used as the example of behavioural genetics while in one focus group alcoholism was used; this focus group was excluded from the present analysis. Respondents were asked to consider: $(a)$ whether they supported research into behavioural genetics; $(b)$ whether they regarded it as different from other types of genetic research and genetic testing; (c) the advantages and disadvantages of behavioural genetic testing; and (d) whether they would consider getting their own child tested.

Both the healthcare professionals and parents were told that genetic testing for behavioural conditions such as violence was hypothetical (that is, did not currently exist), and that such conditions were believed to be multifactorial, meaning that they would involve more than one gene and gene-environment interactions. At most, then, genetic testing would provide an increased propensity or tendency to a particular behaviour but was neither sufficient nor necessary for an individual to display such a behaviour. These background assumptions parallel those held by the Nuffield Council. ${ }^{32}$ The exact wording of the script used in the focus groups is provided in the appendix.

All interviews and focus groups were recorded and audio tapes transcribed. Given the limited sample size, data were examined qualitatively, as well as using SPSS 10 to create cross tabulations and tables. Comparisons were made between respondents on the basis of sex, differences in education, paediatric experience, parenthood, and age.

The University of Chicago institutional review board approved the study. Oral consent was obtained for participation and tape recording from both focus group and healthcare 
professional respondents. Focus group respondents were compensated US\$25 for their participation. The healthcare professionals were interviewed over lunch or coffee.

\section{RESULTS}

When asked whether they would recommend testing a young child with a family history of violence, most (13/21) healthcare professionals would not permit testing. In the case of symptomatic teens with a family history, 12/21 continued to recommend prohibiting such testing. All who permitted testing stated that they would do so only after discouraging parents from testing. The respondents offered many reasons not to test. Among these, the danger of a selffulfilling prophecy was cited by 11 respondents. Healthcare providers were also concerned more generally about labelling and stigmatisation of probands $(\mathrm{n}=8)$, and about how parents and others would treat children differently due to a positive genetic test $(n=7)$. Although many healthcare professionals stated that they could not enumerate any benefits to testing, the most common benefits offered to test a child were: if there were a treatment $(n=8)$; to relieve proband or parental anxiety $(\mathrm{n}=3)$; and for reproductive counselling $(\mathrm{n}=3)$.

In general, the healthcare professionals focused on the medical aspects of diagnosis and treatment of behaviours. For example, a genetic counsellor suggested that the existence of medical treatment is the key factor in testing for behavioural genetics: "If symptomatic, I still don't like the idea of testing an affected teen unless there was a structured treatment based on the genotype" (GENO1).

Even when healthcare professionals mentioned the environment, they continued to focus on medical solutions for behavioural problems. Overall, 6/21 healthcare professionals interviewed mentioned environmental factors in their discussions of behavioural genetics. Some of them noted the potential benefits of environmental changes, as this genetic counsellor suggested it might be possible "to help that child to live in a non-stressful environment" (GEN1l). Yet, even when they mentioned environmental factors, these were often overshadowed by discussions of medical treatments. For example, a paediatrician specialising in genetics highlighted the role of the environment, but then discussed clinical therapies as the key to dealing with violent behaviour (GEN07):

\section{So there's going to be an inability to determine the exact nature as to whether a child would be violent or not based on his genetics ... [I]f you believed a child was born into ... a violent family, so the environmental conditions are right and their genetics were right, with the genetic information you could alter the family's behaviour, which I don't believe you could do, but if you could that might be the pro.... [O]nce this genetic information is available, it's only going to be a short time period between finding of that environment with that genetic information and therapies which might have some reasonable chance of altering the behaviours, so that if you do find serotonin in the receptors, serotonin blockers, or serotonin replacement ... surely these therapies are all going to have to be instituted early so the pro would be therapies when they're available, but only when they're available.}

That is, although the genetic professional mentioned environmental influences and the possibility of improving behaviour through changes in the environment, she quickly dismissed this as unrealistic, and turned to medical therapies instead.
The healthcare professionals often went beyond ignoring environmental influences and treatments for behavioural genetic conditions to suggest that changes in the environment brought on by a positive genetic test would even be detrimental to those tested. In many interviews, they talked about the danger of creating a self-fulfilling prophecy through genetic testing. This may come from the children themselves, as suggested by a genetic counsellor, "I think that kids with problems would just blame it on the gene. I think a kid without problems, if they learned they carried the gene that would be a licence for them to have problems" (GEN01). Many others suggested that a positive genetic test for violence might have a negative impact on how a child is treated by parents, teachers and others in their environment, so that, "by telling people they're genetically predisposed, you might, subconsciously alter the way that they get treated and promote violence in them serendipitously" (paediatrician specialising in genetics, GEN07).

The healthcare professionals generally saw dangers from labelling and stigmatisation that might result from genetic testing for behavioural conditions like violence, fearing the self-fulfilling prophecy. This led them to largely recommend against testing, though leaving open the possibility of testing should clinical therapies become available.

The healthcare professionals were also asked about whether they would test their own children or acquiesce to their teenager's request for testing for a behavioural genetic condition like violence in the presence of a positive family history. In most cases (19/21), respondents would not test their own children, even in the face of symptoms. The two exceptions were both genetic professionals. More (8/21) were willing to accede to test their own teenagers if the teenagers could justify it to them. Again, most of these were geneticists (5/8). In denying a teenager's request for testing, a paediatrician explained, "if you're in trouble you're in trouble doesn't make a difference whether if it's the chicken or the egg ..." (PED03). Another paediatrician said she would allow her teenage daughter to be tested if she were willing to pay out of her allowance, but would not want to test her teenager because it would merely serve "as an excuse to some behaviour" (PED09). Reasons to test or to support their teenager's request for testing were: if there were a treatment $(\mathrm{n}=2)$; symptomatology $(\mathrm{n}=2)$; and reproductive counselling $(n=2)$.

As in the interviews with the healthcare professionals, genetic testing for violent behaviour was presented to focus groups as hypothetical, while the multifactorial nature of behaviour conditions was also highlighted. Most respondents in $9 / 10$ focus groups thought that genetic testing for behaviours was different from other genetic testing. In 10/ 11 focus groups there was mixed support for research into genetic components of violent behaviour. In only one focus group, consisting of all white respondents, participants resoundingly approved of the research. And in three focus groups, at least one respondent suggested this research to be a waste of money, as did this mother (Yvette, mother of 1 , Sanford Health Clinic 3):

I think it's a waste of time, because, okay, you have this research and you done it but there always going to be a question well, how do you know? And where did they get this from, or, I think it's a waste of time, because, okay, now that you know, that you have this slew of genetics here, and you might be violent, that's not going to say that you're going to be a violent person, nor is it going to determine the world, nor is it going to make any changes, Johnny's going to rob the bank next week, it's not going to make a difference, I mean, why study, why waste money? 
Focus group respondents were quite mixed on whether they would want to test their own children for genes associated with violence, should this become feasible. In most groups, some parents thought this information would be detrimental to the child, but others thought it might be useful. Those who wanted to test, argued that they wanted to prepare themselves and their families, to modify the environment or to test once their child begine to seriously and regularly misbehave. Those opposed to testing suggested that violence is mainly a product of the environment, and that testing would not be useful. In all focus groups, respondents raised concerns about labelling and stigmatisation of individuals with a positive test for genes associated with violence. Respondents were concerned about labelling by peers, parents, schools, the workplace, police or other authorities, and healthcare providers and insurers.

Five focus groups spontaneously raised the issue of research and testing for violence in prisons with mixed support for such research. Six (of 11) focus groups mentioned concerns that such research would inappropriately associate race and violence. Notably, the latter concern was mentioned only in focus groups made up of black or a mix of white and black respondents; it was not mentioned by either of the two focus groups of only white participants. On this point, a participant suggested that this research and testing might be dangerously focused on certain populations (Trina, mother of 3, Colby Focus Group):

Do I support the research, if you can find a gene? It comes to, for me, who gets tested for that gene. Who has say so over who gets tested? Realistically, I feel the first people to be tested are going to be young, black males. They're going to test them. Those four white ladies living in the suburbs, chances are they'll never be tested.

By highlighting who might not be tested, this respondent indicated a pronounced concern about the creation of a raced, gendered, and classed violent individual. In contrast with the focus groups, the issue of race and genetic testing was never raised by healthcare professionals in the interviews.

All focus groups mentioned the importance of environment, and respondents in 10/11 focus groups thought that knowing a child had a genetic predisposition would lead to a change in how the child was reared, with respondents in five focus groups considering a modification in diet to curb a child's violent tendencies. Parents interpreted environment broadly to include diet, media, peers, and relationships both within the home and outside it. For example, one mother says, "You can filter out at your home, but what about when they're at the playground? They're out in other environments, birthday parties. What are they seeing?" (Ethel, mother of 3, St Joseph focus group).

This focus on the environment was often raised in contrast to the participants' view of the medicalisation of such issues in the interviews with the healthcare professionals. In 7/11 focus groups, participants spontaneously raised the prevalence of medication of children for supposed attention deficit hyperactivity disorder (ADHD) in the discussion of behavioural genetic testing.

Despite the parental focus on the environment, parents also believed that there could be a genetic component to behaviour. As one parent suggested, parents might turn to genetic testing to understand why a child was having behaviour problems (Amy, mother of 3, Foster focus group):

If I had a child that [sic] was really acting out, I would want to know what was wrong and what was the problem. Was

\section{it something I had done or something that might have} happened while he was born or what?

It is not clear what this respondent would do with the information, and whether it might contribute to the spectre of self-fulfilling prophecy cited by the healthcare professionals in their opposition to testing. But several respondents talked about the reality of a genetic diagnosis. As one mother suggested, "If there is a gene maybe they can't control it, right? ... they might have an excuse which is not good but you have to control it" (Susan, mother of 6, St Nicholas focus group). Another mother, opposed to testing, suggested the danger of this knowledge, echoing the healthcare professionals above (Diana, mother of 3, Sanford Health Clinic focus group 4):

You know a lot of people, a lot of people say we don't, they know they got something they're going to act on it anyway. They're like, "I got the trait anyway, so it's going to come out eventually ... " No, if you control yourself without knowing, what's to say that you, you know, that you'd be able to control yourself with knowing. Is that a better excuse to go out and do something wrong?

Overall, participants did not reach consensus on genetic research or genetic testing of violence either within or across the focus groups. Furthermore, parents were mixed on whether they would test their child or teenager.

\section{DISCUSSION}

Many professional organisations involved in paediatrics and genetics have written consensus statements regarding the issues surrounding genetic testing of children. ${ }^{33-38}$ Although little is said about predictive testing of children for conditions that present in later childhood, ${ }^{39}$ all strongly argue against predictive testing of children for adult onset conditions and carrier status where no childhood interventions will change the course of illness. ${ }^{40-44}$ The statements are silent about genetic testing for behavioural conditions. One reason is that such testing is purely hypothetical at this time. Nevertheless, one could extrapolate that they would not support such testing unless the genetic test had strong predictive value and a proved medical treatment or preventive measure available.

Despite the lack of guidance, there is ongoing research into the genetics of behaviour. In the past decade, headlines have announced and retracted evidence for the "gay gene", 19-21 45-47 and a "gene for intelligence". ${ }^{22-24} 48$ Such research is quite controversial and is used by proponents on both sides of the nature-nurture divide. Research into the ethical, legal, and social implications of behavioural genetics itself provokes controversy as was seen in the politics surrounding a conference to discuss the possibility of genetic roots of criminal behaviour. ${ }^{49}$

Interestingly, we found that healthcare professionals and parents focused on different aspects of behavioural genetics. Throughout the interviews with the healthcare professionals, both the genetic professionals and paediatricians tended to medicalise violent behaviour. The issue of medicalisation is of major concern in the Nuffield Council's report, in particular because it may shift the boundary between normal variation and disorder and reduce social tolerance of previously "normal" behavioural traits. ${ }^{50}$ The Council used the example of prescribing medicines to "children who are disruptive but do not have a clinical diagnosis of hyperactivity, rather than investigating other approaches such as reducing class sizes $^{\prime \prime 51}$; concern about overmedicalisation was also expressed in many of our focus groups. And yet the Council argued that "there is, prima facie, no reason for preferring one type of 
intervention [drugs] over another [environmental changes] as a matter of principle".$^{50}$

Parents, on the other hand, focused on how genetic research into violent behaviour could help them better understand their child and more effectively rear them. Although many healthcare providers and some parents were concerned about self-fulfilling prophecies, many parents believed that knowing the genetic test result of the child could lead to positive changes in a child's environment. There was an assumption that these interventions were safer than medicines, although as the Nuffield report argues, this is not necessarily the case. ${ }^{50}$ Furthermore, some parents and healthcare professionals thought testing might assuage parental guilt by providing a genetic diagnosis or explanation for the behaviour of a violent child. ${ }^{52} 53$

Their respective foci led the healthcare professionals and parents to different conclusions about whether testing should be widely available. The healthcare professionals in general wanted to discourage or refuse to provide genetic testing for behavioural conditions, although in one study approximately a quarter of genetic counsellors supported the development of such testing. ${ }^{54}$ The healthcare professionals only wanted to test if there were treatments available, although $8 / 21$ would have allowed their adolescents to get testing if the latter wanted it. In contrast, parents thought genetic testing for a wide range of other conditions should be available (unpublished observation), although they were more ambivalent about whether, when, and why they would test their own children. Parents often advocated testing regardless of the lack of medical treatments to figure out what was going on with a symptomatic child or to prevent the emergence of violent behaviours through environmental modifications.

Of course, whether parents would actually seek testing if it were available is not known. Genetic tests for untreatable conditions are not widely available. One available genetic test is for Huntington's disease (a progressive form of early onset dementia transmitted in an autosomal dominant fashion with virtually $100 \%$ penetrance). Here, the data show that many fewer will seek testing than proclaim interest in access. Despite surveys reporting interest in testing by over $70 \%$ of at risk family members, ${ }^{55}{ }^{56}$ less than $20 \%$ have sought testing to date..$^{57} 58$

Although both healthcare professionals and parents were concerned about the stigma and discrimination that could be associated with such testing, only parents highlighted the potential interaction of racial discrimination with stigmatisation and discrimination resulting from a positive genetic test. Empirical data regarding stereotypes about race and crime are provided by Andrews who suggests that such data "may make it more likely that researchers will look for a gene for aggression or criminality in a minority population." 59 Andrews $^{60}$ also suggests that research into links between violence and genes may lead to support for gene or drug interventions, particularly directed at minorities. In contrast, although Parens agrees that "in the imagination of many Americans there are powerful links between race, crime, and genes" that are worrisome in a racist society such as ours, he argues that "in the case of blacks and criminal behavior, no research has been done, nor can one imagine any creditable research being done." ${ }^{61}$ King, however, offers one argument about why such research is dangerous to racial and ethnic minorities: "greater attention will be paid to genetic explanations than to more complex explanations for differences to the detriment of vulnerable and disadvantaged groups." 62

An important limitation of this study is that the healthcare professionals and focus groups were not statistically representative but represented convenience samples. Nevertheless, we did seek medical respondents from various institutions with various training and led focus groups in various communities to achieve both racial and economic diversity. In addition, although our sample sizes are small, we conducted enough interviews with healthcare professionals and parents that we were no longer hearing new ideas. However, we did not sample families with a known genetic condition and there are data to suggest that they may have different attitudes. ${ }^{63}$

A second limitation is that while doctors were interviewed one to one, parental opinions were obtained through focus groups. It is likely that these different research methods produced different responses. We chose interviews for the healthcare professionals because we were studying several different research questions, answers to some of which could not be obtained in a group. We also sought to minimise the time demands and to be flexible with respect to their schedules. We chose focus groups for our lay participants, in part, to maximise the number of possible voices heard. In addition, the respondents were being asked to consider a hypothetical situation that was far from their lived experiences, and the focus group structure allows for the exploration and discussion of previously unfamiliar medical and genetic information among respondents. ${ }^{64}$ These exchanges allowed the respondents together to explore their individual understandings and reactions to genetic information and testing. During the course of the focus groups, it is likely that some individual voices were not heard, as some respondents did not speak out, ${ }^{65}$ and others were swayed by dominant voices. ${ }^{66} 67$

Our study does have several policy implications. First, given the different foci of healthcare professionals and a nonvested lay public, our data suggest that both populations need to be at the table in policy development, along with academics and individuals with experience of chronic genetic conditions. ${ }^{6}$ Secondly, the rapid progress in genetic research will require a re-evaluation of what guidelines or regulations ought to control the provision of new genetic tests, particularly in a medical system that is market driven. ${ }^{69-72}$ This is particularly true for genetic testing for behaviours in which the tests can only show an increased propensity but will never yield a more conclusive diagnosis.

\section{CONCLUSION}

Although behaviour may be too complex for a gene test or cluster of tests to provide any robust prediction, research continues in this area. Therefore, it is important to examine the concerns of both parents and healthcare providers to ensure that they are taken into account if and when such tests become available. In our data, we found important differences in the concerns expressed by healthcare professionals and parents regarding behavioural genetics. While the healthcare professionals focused on medical factors and worried about parental misuse of such information, parents focused on environmental factors, worrying about the misuse of such information by the medical and legal establishments. Public dialogue between healthcare professionals and parents is important so that they may hear each other's voices surrounding this research and technology, and to ensure that policies are devised that accommodate both sets of concerns, without forgetting that the primary focus of any health policies for children should be to promote the wellbeing of children.

\section{ACKNOWLEDGEMENTS}

We would like to thank the healthcare professionals who graciously agreed to be interviewed and the parents who participated in our focus groups. We would like to thank $\mathrm{M}$ Justin Coffey for his help at many stages in the project. We would also like to thank our Advisory Board, and the reviewers for the Journal of Medical Ethics for their thoughtful suggestions. 


\section{Authors' affiliations}

E Campbell, Department of Sociology, University of Chicago, Chicago, IL, USA

L F Ross, Department of Pediatrics and the Maclean Center for Clinical Medical Ethics, University of Chicago, Chicago, IL, USA

The authors were supported by a Harris Foundation Grant, Ethical Analysis and Public Policy Recommendations Regarding the Genetic Testing of Children.

\section{APPENDIX}

\section{BEHAVIOURAL GENETICS SCRIPT}

While the main focus on clinical genetic research to date is on diseases, some work is being done to try to understand complex behaviours. For example, some research is being done to understand to what extent tendency to violence is inherited. We know that there is no one gene that can predict whether an individual will be violent, but that there are some genes that increase the risk. However, behaviours like violence are complex and depend on many genes plus the interaction between one's genes and one's environment (this includes how one is raised as well as one's nutrition, the schools which one attends, whether one lives in a city or on a farm, one's interactions with one's siblings, etc). This means that even if all the genes that help determine violence were known, we would not know if a person who had those genes would be violent. Rather, in complex conditions (like high blood pressure and violence), environment plays a very important role in influencing whether the genes express and how strongly they express.

\section{REFERENCES}

1 Jacobs PA, Brunton M, Melville MM, et al. Aggressive behavior, mental subnormality, and the XYY male. Nature 1965;208:1351-2.

2 Witkin HA, Goodenough DR, Hirschhorn K, XYY men: are they criminally aggressive? Sciences-New York 1977;17:10-13.

3 Culliton B. XYY: Harvard researcher under fire stops newborn screening. Science 1975;186:1284-5, at 1284.

4 Steinfels $M O$, Levine $C$. The $X Y Y$ controversy: researching violence and genetics. Hastings Cent Rep 1980;10:1-32.

5 Andrews L. Predicting and punishing antisocial acts. In: Carson R, Rothstein M, eds. Behavioral Genetics: The Clash of Culture and Biology. Baltimore MD: Johns Hopkins University Press, 1999;116-56, at 124-6.

6 Baron M. Crimes, genes, and responsibility. In: Wasserman D, Wachbroit R, eds. Genetics and Criminal Behavior. Cambridge: Cambridge University Press, 2001;201-23 at 209

7 Brunner HG, Nelen M, Breakfield XO, et al. Abnormal behavior associated with a point mutation in the structural gene for monoamine oxidase. Science 1993:262:578-80.

8 Brunner HG. MAOA deficiency and abnormal behaviour: perspectives on an association. Ciba Foundation Symposium 1996;194:155-64, discussion 164-7.

9 Verkraik R. It's in my genes, m'lud; American lawyers are trying to use genetic evidence to reduce their clients' sentences. Could it work in Britain? The Independent (London) May 10, 1995;Law: 31.

10 See reference 5: 116-17.

11 Carson R, Rothstein M, eds. Behavioral Genetics: The Clash of Culture and Biology. Baltimore MD: Johns Hopkins University Press, 1999.

12 Wasserman D, Wachbroit R, eds. Genetics and Criminal Behavior. Cambridge UK: Cambridge University Press, 2001.

13 Andrews L. Future Perfect. New York: Columbia University Press, 2001

14 Nuffield Council on Bioethics. Genetics and human behaviour. London: Nuffield Council on Bioethics, 2002:xxi.

15 Savulescu J, Robertson S. Is there a case in favour of predictive genetic testing in young children? Bioethics 2001;15:27-49.

16 Dalby S. GIG response to the UK Clinical Genetics Society report. J Med Genet 1995;32:490-4.

17 Clarke A. Parents' responses to predictive testing for their children. J Med Genet 1997;34:174-5.

18 See reference 14: appendix 2: 195

19 Anonymous. Researchers link gene pattern, male homosexuality. St Louis Post-Dispatch (Missouri) July 16, 1993:8A

20 Painter K. Is there a gay gene? Key evidence: more maternal kin are gay. USA Today July 16, 1993:1A.

21 Petit C. New evidence of "gay gene" in some men. Study says hereditary trait is passed along by mothers. The San Francisco Chronicle July 16, 1993:A1.

22 Reuter. Brainy sons owe it all to mom; geneticists say. The Toronto Star June 28, 1996:A3.

23 Connor S. Scientists find gene for intelligence. Times Newspapers (London) October 19, 1997, home news.
24 Wade N. Gene linked to high IQ is reported found with new technique. New York Times May 14, 1998;2:A16.

25 Nelkin D, Lindee MS. The DNA Mystique: The Gene as Cultural Icon. See Ch. 6: Creating Natural Distinctions. New York: Freeman, 1995:102-6.

26 See reference 13: 145-80.

27 Rothstein MA. Behavioral genetic determinism: its effects on culture and law. In: Carson R, Rothstein MA, eds. Behavioral Genetics: The Clash of Culture and Biology. Baltimore MD: Johns Hopkins University Press, 1999:90-115.

28 Rose SPR. Neurogenetic determinism and the new euphenics. BMJ 1998;317:1707-08.

29 Murray TH. Genetic exceptionalism and "future diaries": is genetic information different from other medical information. In: Rothstein MA, ed. Genetic Secrets: Protecting Privacy and Confidentiality in the Genetic Era. New Haven: Yale University Press, 1997:60-73, at 71.

30 See reference 14: appendix 2.

31 Campbell E, Ross LF. Professional and personal attitudes about access and confidentiality in the genetic testing of children: a pilot study. Gen Testing 2003;7:123-30.

32 See reference 14: xxi-xxii.

33 Institute of Medicine. Assessing Genetic Risks: Implications for Health and Social Policy. Washington DC: National Academy Press, 1994.

34 Working Party of the Clinical Genetics Society (UK). The genetic testing of children. J Med Gen 1994;31:785-97.

35 American Society of Human Genetics (ASHG)/American College of Medical Genetics (ACMG). Points to Consider: Ethical, Legal, and Psychosocial Implications of Genetic Testing in Children and Adolescents. Am J Hum Gen 1995;57:1233-41.

36 American Academy of Pediatrics (AAP), Committee on Bioethics. Ethical issues with genetic testing in pediatrics. Pediatrics 2001;107:1451-5.

37 Nuffield Council on Bioethics. Genetic Screening-Ethical Issues. London: Nuffield Council on Bioethics, 1993

38 Human Genetics Society of Australasia. Predictive testing in children and adolescents. 2003; www.hgsa.com.au/policy/ptca.html (accessed on).

39 See reference $34: 787$

40 See reference 33:10.

41 See reference 35:785.

42 See reference 36:1233.

43 See reference 37:1453, 1454

44 See reference 35: Introduction, Background.

45 Crewdson J. Gay gene theory is not backed up by other studies; Allegations of selective data probed. Houston Chronicle June 26, 1995.

46 Hawkes N. Scientists dismiss gay gene theory. The Times (London) April 23, 1999, home news.

47 Anonymous. New study can't locate "gay gene". Chicago Sun-Times April 23, 1999:37.

48 AP. In new study, genes get less credit for human intelligence. St Louis PostDispatch (Missouri) July 31, 1997:08A.

49 Wasserman D, Wachbroit R. Introduction: methods, meanings, and morals In: Wasserman D, Wachbroit R, eds. Genetics and Criminal Behavior. Cambridge UK: Cambridge University Press, 2001:1-21, at 3-4.

50 See reference 14: xxv.

51 See reference 14: section 13.22, 138.

52 See reference 25: 138,139,142.

53 Nelkin D. Behavioral genetics and dismantling the welfare state. In: Carson R, Rothstein M, eds. Behavioral Genetics: The Clash of Culture and Biology. Baltimore MD: Johns Hopkins University Press, 1999:156-71, at 167.

54 Brown TC, Wertz DC, Fox RC, et al. Ethical perspectives of genetic counselors: does area of specialty matter? National Society of Genetic Counselors 1999 Education Conference [abstract]. J Gen Couns 1999:8:413-414.

55 Schoenfeld $\mathbf{M}$, Myers RH, Berkman B, et al. Potential impact of a predictive test on the gene frequency of Huntington disease. Am J Med Gen 1984; 18:423-9.

56 Stern R, Eldridge R. Attitudes of patients and their relatives to Huntington's disease. J Med Genet 1975;12:217-23.

57 Craufurd D, Dodge A, Kerzin-Storrer L, et al. Uptake of presymptomatic predictive testing for Huntington's disease. Lancet 1989;ii:603-5.

58 Quaid KA, Brandt J, Folstein SE. The decision to be tested for Huntington's disease. JAMA 1987;257:3362.

59 See reference 5:133.

60 See reference 13:94.

61 Parens E. Taking behavioral genetics seriously. In: Howell JH, Sale WF, eds. Life Choices. Washington DC: Georgetown University Press, 2000:556-69, at 565.

62 King PA. The past as prologue: race, class, and gene discrimination. In: Annas GJ, Elias S, eds. Gene Mapping: Using Law and Ethics as Guides. New York: Oxford University Press, 1992:94-111, at 102.

63 Duster T. The social consequences of genetic disclosure. In Carson R, Rothstein M, eds. Behavioral Genetics: The Clash of Culture and Biology. Baltimore MD: Johns Hopkins University Press, 1999:172-88.

64 Kerr A, Cunningham-Burley S, Amos A. Drawing the line: an analysis of lay people's discussions about the new genetics. Public Understand Sci 1998;7:113-33, at 130.

65 Stewart DW, Shamdasani PN. Focus groups: theory and practice. Newbury Park, CA: Sage Publications, 1990.

66 Channock SJ, Kundra V, Johnson FL, et al. The other side of the bed: what care givers can learn from listening to patients and their families. In: Pizzo $P$, Poplack D, eds. Principles and practice of pediatric oncology. Philadelphia: Lippincott-Raven, 1997:1267-82. 
67 Carey MA, Smith MW. Capturing the group effect in focus groups: a special concern for analysis. Qual Health Res 1994;4:123-7.

68 Hiller EH, Landenburger G, Natowicz MR. Public participation in medical policy-making and the status of consumer autonomy: the example of newborn-screening programs in the United States. Am J Pub Health 1997;87:1280-8.

69 Human Genetics Commission. GENES DIRECT: Ensuring the effective oversight of genetic tests supplied directly to the public. March, 2003. On the web at www.hgc.gov.uk/genesdirect/genesdirect_full.pdf (accessed on July 19 2004).

70 Lee TA, Brennan TA. Direct-to-consumer marketing of high-technology screening tests. N Engl J Med 2002;346:529-31.

71 Williams-Jones B. Where there's a web, there's a way: commercial genetic testing and the internet. Comm Gen 2003:6:46-57.

72 Levitt M. Let the consumer decide? The regulation of commercial genetic testing. J Med Ethics 2001;27:398-403.

\section{Clinical Evidence-Call for contributors}

Clinical Evidence is a regularly updated evidence-based journal available worldwide both as a paper version and on the internet. Clinical Evidence needs to recruit a number of new contributors. Contributors are healthcare professionals or epidemiologists with experience in evidence-based medicine and the ability to write in a concise and structured way.

Areas for which we are currently seeking authors:

- Child health: nocturnal enuresis

- Eye disorders: bacterial conjunctivitis

- Male health: prostate cancer (metastatic)

- Women's health: pre-menstrual syndrome; pyelonephritis in non-pregnant women

However, we are always looking for others, so do not let this list discourage you.

Being a contributor involves:

- Selecting from a validated, screened search (performed by in-house Information Specialists) epidemiologically sound studies for inclusion.

- Documenting your decisions about which studies to include on an inclusion and exclusion form, which we keep on file.

- Writing the text to a highly structured template (about 1500-3000 words), using evidence from the final studies chosen, within 8-10 weeks of receiving the literature search.

- Working with Clinical Evidence editors to ensure that the final text meets epidemiological and style standards.

- Updating the text every six months using any new, sound evidence that becomes available. The Clinical Evidence in-house team will conduct the searches for contributors; your task is simply to filter out high quality studies and incorporate them in the existing text.

- To expand the topic to include a new question about once every 12-18 months.

If you would like to become a contributor for Clinical Evidence or require more information about what this involves please send your contact details and a copy of your CV, clearly stating the clinical area you are interested in, to Klara Brunnhuber (kbrunnhuber@ bmigroup.com).

\section{Call for peer reviewers}

Clinical Evidence also needs to recruit a number of new peer reviewers specifically with an interest in the clinical areas stated above, and also others related to general practice. Peer reviewers are healthcare professionals or epidemiologists with experience in evidence-based medicine. As a peer reviewer you would be asked for your views on the clinical relevance, validity, and accessibility of specific topics within the journal, and their usefulness to the intended audience (international generalists and healthcare professionals, possibly with limited statistical knowledge). Topics are usually 1500-3000 words in length and we would ask you to review between 2-5 topics per year. The peer review process takes place throughout the year, and our turnaround time for each review is ideally 10-14 days.

If you are interested in becoming a peer reviewer for Clinical Evidence, please complete the peer review questionnaire at www.clinicalevidence.com or contact Klara Brunnhuber (kbrunnhuber@bmigroup.com). 